\title{
The Necessity of Domestic Flights at Business Trips - A Theoretical and Empirical Study Under the Aspect of Climate-Friendly Alternatives
}

\author{
Daniela Ludin \\ Heilbronn University of Applied Sciences \\ Wanja Wellbrock \\ Heilbronn University of Applied Sciences \\ Erika Müller \\ Heilbronn University of Applied Sciences \\ Wolfgang Gerstlberger \\ Tallinn University of Technology \\ Kristina Kljevkovic \\ Heilbronn University of Applied Sciences \\ Daniel Michel \\ Heilbronn University of Applied Sciences
}

\begin{abstract}
Airplanes, one of the most popular means of transport, have a significant influence on greenhouse gas emissions in Germany. While air travel is indispensable for large distance traveling, there are more climate-friendly alternatives for short distances. Therefore, especially domestic flights, which are often used for business trips, should be considered critically. The question arises to what extent domestic flights are compatible with CSR activities of companies and whether business-related domestic flights are necessary. Could they be replaced by more environmentally sustainable means of transport, e.g. by train? In addition, if not, what are the reasons? Beyond that, the question arises why business trips within Germany are carried out at all. Is it possible to replace a business trip by using alternative digital communication methods? For this study, a survey among business travelers at Stuttgart Airport is used to examine the necessity of as well as motivations and alternatives for domestic flights under the aspect of sustainability.
\end{abstract}

Keywords: sustainability, domestic flights, business trips 


\section{INTRODUCTION}

\section{Problem and Relevance}

Climate neutrality by 2050 for Europe. This is the goal that the European Union set itself at the EU conference, which took place in December 2019 in Brussels (European Council, 2019). Because of the EU summit's decision, any greenhouse gas emission is now to be compensated; either stored or avoided (European Council, 2019). Airplanes, one of the most popular means of transport, have a major influence on greenhouse gas emissions in Germany. While air travel is an indispensable means of transport for distant destinations, there are more climate-friendly alternatives for short distances. Among the aspects mentioned at the beginning, especially domestic German flights should be considered critically. They are often used for business trips by companies as well as by private consumers.

\section{Objective}

The aim of this paper is to find out, to what extent domestic flights within Germany are necessary for business trips, especially under the aspect of sustainability. It will be determined whether the aspect of sustainability plays a role in the decision-making process at all. Furthermore, this paper aims to find out why business travelers choose to travel by airplane and whether greener, more sustainable means of transport are an appropriate alternative. Moreover, this paper aims to find out why business trips within Germany are carried out at all and if they can be replaced by digital communication methods.

\section{METHODOLOGY}

\section{Research-Leading Questions}

Based on the theoretical findings, concrete questions were developed, which guide the empirical investigation of the following study. The research-leading questions, shown in Table 1, form the basis for the areas that are relevant to the study of the issue. They were answered in the course of this paper to give factual and content-related precise statements.

TABLE 1

\section{RESEARCH LEADING QUESTIONS}

\begin{tabular}{|c|c|c|}
\hline Nr. & Research-leading questions & Methodology \\
\hline & \multicolumn{2}{|l|}{ Sustainability sciences } \\
\hline 1 & What does sustainability mean? & Literature Analysis \\
\hline 2 & What is $\mathrm{CO}_{2}$ neutrality and $\mathrm{CO}_{2}$ compensation? & Literature Analysis \\
\hline 3 & $\begin{array}{l}\text { To what extent have environmental aspects played a role in the decision- } \\
\text { making process regarding the transportation of a domestic business trip? }\end{array}$ & Survey \\
\hline \multirow[t]{2}{*}{4} & Does the topic of $\mathrm{CO}_{2}$ compensation already play a role in companies? & Survey \\
\hline & \multicolumn{2}{|l|}{ Sustainable mobility } \\
\hline 5 & What is meant by sustainable mobility? & Literature Analysis \\
\hline 6 & What are sustainable means of transport for business trips? & Literature Analysis \\
\hline \multicolumn{3}{|c|}{ Organizational communication } \\
\hline 8 & What is a business trip? & Literature Analysis \\
\hline 9 & What are the reasons for business trips in companies? & Literature Analysis \\
\hline 10 & How do business trips contribute to organizational communication? & Literature Analysis \\
\hline 11 & What is the reason for companies to conduct business trips in Germany? & Survey \\
\hline 12 & Which alternative communication options could replace a business trip? & Survey \\
\hline
\end{tabular}

Source: Own Illustration 


\section{Methodological Approach}

A methodological approach involves the empirical examination of theoretical hypotheses. This includes the way research instruments are used. A distinction is also made between primary and secondary research (Atteslander, 2010). Within the scope of primary research, data is collected, analyzed and interpreted for the first time for an existing object of investigation. Data records from already existing information sources are collected and processed in the secondary analysis (Meffert et al., 2019). In order to achieve the defined objectives of this study, the literature analysis, as well as the survey were considered as methodical procedures in the present study. While the literature analysis belongs to secondary research, the survey classifies as primary research.

\section{Literature Analysis}

Meticulous scientific studies are based on thorough research of the relevant specialist literature. The aim here is to get to know and describe the current state of research and to develop a theoretical background for the study. A critical review of the current state of research as well as of the theoretical background is insofar essential in order to systematically derive and conclusively justify appropriate research questions (Döring \& Bortz, 2016). The literature research started with the categorization of the topic into its respective scientific fields. Subsequently, scientific articles published in peer-reviewed journals concerning the scientific fields were analyzed to determine the current state of knowledge.

\section{Survey}

This study is based on a survey of business travelers at the airport in Stuttgart, Germany. A survey means a communication between two or more persons. Verbal questions evoke verbal answers. An individual's answers relate to what he or she has experienced and remembered during social events and represent individual opinions and judgements (Atteslander, 2010).

Since business travelers have been surveyed at the airport in Stuttgart, it was already assumed before that the respondents would only have a limited amount of time available at the survey location. Accordingly, the respondents received a link to an online questionnaire, which could be filled out during the waiting time. This link was shared by using a so-called Quick Response Code, abbreviated as QR-Code. The QRCode consists of a square matrix containing data. These data can then be read out using a software program. By having the reader using e.g. a smartphone, point at the code and scan it, the software can decode the code and the user is redirected to the corresponding website behind the code. The main advantage is that the error-prone and time-consuming typing of a web address can thus be avoided (Kreutzer, 2014).

The benefit of this approach was that users could visit a specific desired website in a very simple and efficient way. Using the QR Code was aimed to minimize the time expenditure of the respondents and thus to maximize the response rate.

The survey was conducted with a standardized survey questionnaire. Answers to a standardized question were grouped into categories in order to make them comparable. The categorization of the answers can be done before the interview or afterwards. If the answer categories are defined in advance, they can be submitted simultaneously to the respondent in the case of a self-contained question (Atteslander, 2010). Comparability was the reason for choosing the standardized questionnaire. For the same reason, mainly self-contained questions were used in this survey.

\section{THEORETICAL FOUNDATIONS}

\section{Classification Into the Scientific Fields}

Science is a systematic exploration, collection and evaluation of knowledge. In order to discuss a generally valid definition for a specific scientific field, interdisciplinary exchange processes take place worldwide (Balzert et al., 2010). This study paper, which deals with the necessity of domestic flights at business trips, includes the fields of sustainability sciences, sustainable mobility and organizational communication (Figure 1). 


\section{FIGURE 1 \\ CLASSIFICATION INTO SCIENTIFIC FIELDS}

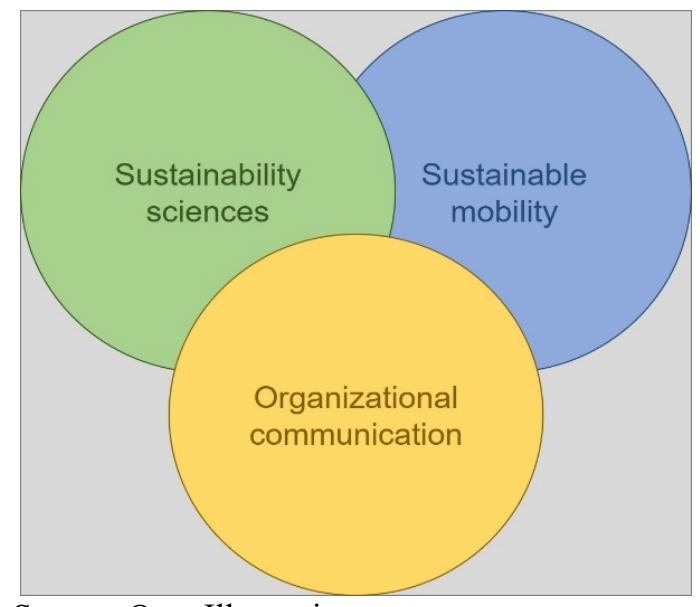

Source: Own Illustration

\section{Sustainability Sciences}

The term sustainability originally stems from the field of forestry. According to this, sustainable forest management is based on felling only as much wood as can be harvested in one year, so that a constant and consistent amount of wood can be harvested again to ensure that the forest is preserved and can be managed over a sustained period (Heinrichs \& Michelsen, 2014). From a political perspective, a definition from the Brundtland Report of 1987 is considered. It implies that sustainable development meets the needs of the present without compromising the ability of future generations to meet their own needs (Binder, 2013, p.20).

The science of sustainability is based on three dimensions, which are equally weighted within the model: economy, ecology and social issues. These pillars of sustainability should be seen as autonomous but interlinked subsystems, which form the basis for the satisfaction of human needs. Consequently, a society can be threatened by economic, ecological or social risks (Heinrichs \& Michelsen, 2014, p.29). The ecological dimension includes the natural environment. Conservation of resources, reduction of air, water and soil pollution, climate protection and the preservation of biodiversity are the central objectives to protect the environment. For instance, the ecological goal of resource conservation can only be achieved, if the degradation or depletion rate of renewable resources does not exceed their regeneration rate. Social sustainability is based on the fundamental social norms of justice, security and peace in order to protect people as well as the environment. Its central objectives are to combat poverty, oppression and exploitation, to improve education and training for everyone in the society, to protect and promote human health and to avert discrimination. The purpose of economics is to maintain and secure competitive and market functions on a long-term basis. This means that a society should not live economically beyond its means in order not to burden future generations (Balderjahn, 2013, p.21f).

Society is in a state of upheaval, which is addressed directly to politics. Therefore, the German government has set challenging and ambitious objectives: Greenhouse gas emissions are to be reduced by $40 \%$ until 2020 and by $55 \%$ until 2030 (Blum et al., 2019). The transportation sector is one of the main sources responsible for greenhouse gas emissions. $24 \%$ of global energy-related $\mathrm{CO}_{2}$ emissions come from the transport sector (Statista Research Department, 2018). In order to limit these emissions, the European aviation sector is required to participate in the European Emissions Trading Scheme since January 1, 2012. This affects all airlines that take off or land on this continent (Scharschmidt \& Lippelt, 2012). Due to the current climate discussions, the economy has also set itself the goal of becoming more climate neutral. $\mathrm{CO}_{2}$ describes the chemical structural formula for carbon dioxide, which is a gas occurring in nature and is harmless to humans and animals in low concentrations and is even necessary, e.g. for the photosynthesis of plants. A distinction must be made here between gases formed by technical processes, also known as 
greenhouse gas, which in large quantities cannot be neutralized by nature ("Glossary: Carbon dioxide emissions," 2017). Nevertheless, the term $\mathrm{CO}_{2}$-neutrality is used in an inflationary way, as there is neither a clear definition nor clear target for politics or companies. In the context of $\mathrm{CO}_{2}$ neutrality in companies, greenhouse gas emissions are compensated by internal or external measures. External measures include, for example, regular financial support for climate protection projects, which have no link to the company itself. Internal measures are taken where the company influences or can influence internal investment decisions in terms of sustainability (Bode \& Lüdeke, 2007). Further compensation options can also include investments in environmental projects supporting social and ecological development that are certified according to strict standards.

\section{Sustainable Mobility}

The concept of sustainable mobility underlies no clear definition. The scientific field of transport science will be used as a basis for deriving the research area of sustainable mobility.

The science of transport is based on the concepts of transport and mobility. Within the field of transport science, transport is defined as the movement of people and goods. The literature distinguishes between freight and passenger transport. While freight transport arises from the spatial division of labor, passenger transport is a result of the human need for mobility. Both types of transport are organized by linking modes of transport, means of transport and transport stations with the help of traffic routes and different types of transport (Stock \& Bernecker, 2014, p.1). In the literature rail, road, shipping and air are defined as the most classical modes of transport. Means of transport are transport objects (train, plane, ship), which are capable of transporting people and goods by water, on land, in the air and in space. In combination with the transport route, the traffic stations form the transport infrastructure (Ludin, 2011, p.91). A well-developed and organized transport infrastructure is the prerequisite for physical movement of goods and people transport (Stock \& Bernecker, 2014, p.1).

A difference must be made between transport and the term "mobility". In general, mobility is understood as the movement of people or goods between the subsets of a system. In the context of spatial mobility, a location defines the subset and space of the system. Accordingly, spatial mobility involves the change between at least two locations and manifests itself in a physical overcoming of space. Overcoming space requires time, so the time component must also be considered in the mobility concept (Stock \& Bernecker, 2014, p.2).

The principle of sustainable mobility is to ensure the mobility of people and goods in such a way, that the volume of traffic does not place an excessive burden on people and the functioning of the environmental budget. The objectives of sustainable mobility are to meet mobility needs of broad sections of the population and disadvantaged groups in the existing transport system but to design it in an environmentally compatible manner. Disadvantaged population groups are defined by the fact that certain groups of people are severely restricted in their mobility due to their physical location. Included are for example children in cities or elderly people in rural regions (Ministerium für Verkehr Baden-Württemberg, n.d.). However, society's demand for constant mobility leads to a direct impact on the environment and society itself. Social burdens include noise as well as an overuse of land. The high amount of energy needed to drive means of transport and the associated air pollution lead to increased environmental pollution. The overburdening of traffic and the associated lack of safety are classified in the literature as socioeconomic burdens (Janic, 2003). Thereby, according to the WHO, air pollution is defined as the contamination of indoor and outdoor air inhaled by humans through chemical, biological or physical pollutants. These can have a direct impact on the cardiovascular system as well as the respiratory tract. Moreover, in 2013, the International Cancer Research Centre of the WHO classified pollution of the outside air as carcinogenic. Main sources are agriculture, energy, industry, trade, waste management and transport. In order to reduce pollutant emissions from modes of transport, federal states and local authorities want to improve public transport in urban areas as well as the infrastructure needed for pedestrians, cyclists and rail traffic between the cities (WHO-Regionalbüro für Europa, n.d.). Emissions of greenhouse gases from trains and airplanes result from different energy sources. While high-speed trains today are already electrically powered, airplanes use kerosene as their engine fuel. Consequently, airplanes emit considerably more pollutants into the outside air in the form of 
$\mathrm{CO}_{2}$ than battery-powered electric trains (Steinemer et al., 2015, p.495). As of 2019, there is currently no optimal way to make air transport sustainable. It is estimated that battery-powered airplanes will not be feasible by 2050. Environmentally friendly alternatives for energy production are hydrogen and biofuel. Since the energy density of hydrogen is too low which would lead to significant safety problems, the actual strategy in air transportation is focused on biofuel. Current problem here is the scarce supply of renewable resources (Goede, 2018).

\section{Organizational Communication}

The scientific field of organizational communication has developed from the interface between organizational research and communication science and focuses on internal and external communication processes. Within organizational communication, the participants act in their role as members or representatives in the interest of their organization. The processes of organizational communication are to be considered on the micro-, meso- and macro-level: At the micro-level, the focus is on the communication between individuals or departments (internal communication). The meso-level deals with the communication between individual departments of an organization (internal communication) or other organizations (external communication). In contrast, the macro level refers to the communication processes between organizations and their social environment (external communication) (Theis-Berglmair, 2003, p.565f).

In order to be able to operate in their business field in the long term, globally active organizations must have optimum control of internal communication between the various locations of their own company as well as communication with external business partners, e.g. with customers or suppliers (Deutsches Institut für Interne Revision e.V., 2015, p.11). One of the main reasons for the growing need for communication with third parties is increasing globalization. Nowadays, geographically distant business partners and project teams are part of everyday business life. Cross-location departments, increasingly flattening hierarchies and the growing independence and self-empowerment of employees are key reasons for the necessity of a barrier-free internal communication.

One channel for organizational communication are business trips. A business trip is defined as a workrelated trip to an irregular place of work. It serves the purpose of, e.g., strengthening business relations with key customers, acquiring new customers, conducting negotiations with suppliers, participating in internal company conferences or attending an industry-specific trade fair in the capacity of a consultant or representative (Aguilera, 2008). Business trips form an important channel of communication within organizations, since they have the advantage of direct and personal contact (Deutsches Institut für Interne Revision e.V., 2015, p.11).

Alternative communication channels are inter-based information and communication technologies, commonly known as ICT. The data exchange here takes place via a suitable IT infrastructure and can replace business trips and thus face-to-face communication (Sczcutkowski, 2018). Common types of ICT are e-mail, telephone or video conferencing (Aguilera, 2008, p.1110). Especially video conferences, which enable digital face-to-face communication, can significantly reduce the number of business trips. Next to cost and timesaving for a company and its employees, ICT can also contribute significantly to the reduction of $\mathrm{CO}_{2}$ emissions (Guerin, 2017). Because of the growing general environmental public awareness and its impact on a company's image, reducing $\mathrm{CO}_{2}$ emissions is becoming increasingly important for the strategic and operational planning of a company (Poom et al., 2017, p.292).

\section{EMPIRICAL RESEARCH}

\section{Description of the Research Area and Research Subject}

As part of the survey, business travelers on a domestic flight were interviewed at Manfred Rommel Airport in Stuttgart. With its airport STR sustainability strategy, the airport company itself has set the goal to reduce greenhouse gas emissions by $50 \%$ by 2030 compared to 1990 levels. By 2050, airport operations should be completely climate neutral. First measures are the use of electric vehicles within the airport grounds and the reduction of aircraft taxiing times between the runway and the landing strip in order to 
keep $\mathrm{CO}_{2}$ emissions as low as possible. In the first year, 740 tons of $\mathrm{CO}_{2}$ were saved. In addition, Stuttgart Airport promotes research in electric aircraft (Flughafen Stuttgart GmbH, n.d).

The airport is a suitable location for the study, not only from the sustainability aspect but also because of the approximately 30.000 daily passengers in civil air traffic (Flughafen Stuttgart, GmbH, 2018, p.31). The survey took place on 25 November 2019 between 05:30 and 10 am. Based on the assumption that many business travelers would be encountered on a Monday morning, this survey period was deliberately defined. Beforehand, participants were filtered by their individual reason for travelling and their destination. The criteria „business trip" and a "destination airport within Germany" qualified people to participate in the survey. Subsequently, the qualified participants were presented with a handout providing the essential information on the survey topic; names of the interviewing students, link in text form as well as a QR code to the questionnaire. The aim was to make the survey time-efficient and comfortable for the respondents. Eventually 20 business travelers took part in the survey.

\section{Results From Sustainability Science}

In the context of sustainability science, the interviewees were first asked about the importance of the topic of sustainability in their company (Figure 2).

\section{FIGURE 2}

\section{IMPORTANCE OF SUSTAINABILITY IN COMPANIES}

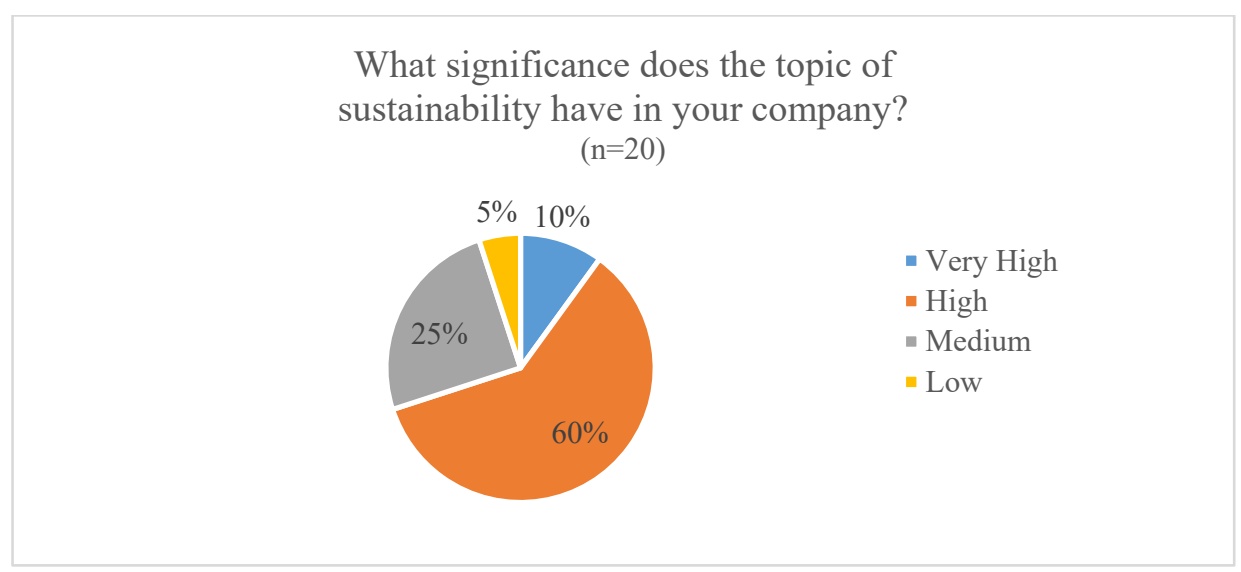

Source: Own Research

The respondents had the possibility to choose between low, medium, high and very high. Most respondents stated that the importance of sustainability is high in their company. 14 of the 20 respondents stated that they work in companies where sustainability is a high or very high priority. $25 \%$ of the interviewees indicated the expression "medium". Only one respondent stated that he or she was employed in a company where the issue of sustainability plays a minor role. This result could be due to the increasing relevance of sustainability in the economy and society. Whether and to what extent the aspect of sustainability is anchored in the corporate strategy is not comprehensible within this study due to the anonymity of this question. 
FIGURE 3

ROLE OF SUSTAINABILITY IN THE SELECTION OF TRANSPORT ROUTE

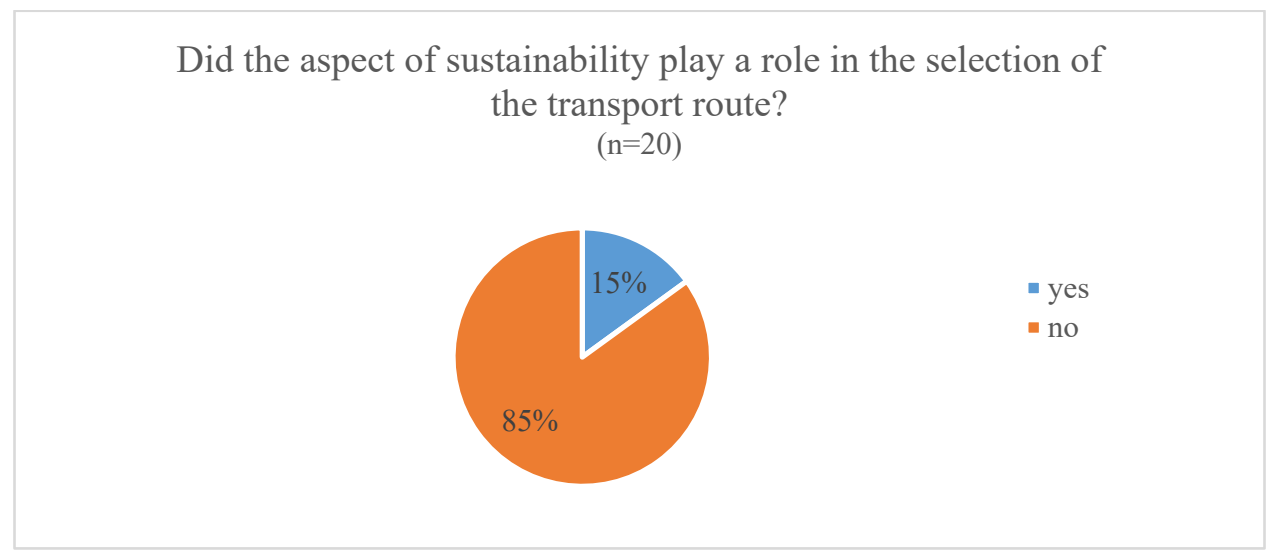

Source: Own Research

The following question "Did the aspect of sustainability play a role in the selection of the transport route" could be answered with the answer options "Yes" and "No" (Figure 3). Respondents were also given the opportunity to justify the answer. $85 \%$ of the respondents stated that the aspect of sustainability did not play a role in the selection of the transport route. As justification, two respondents stated that it did not play a role due to a lack of alternatives. One business traveler stated that travel time was much more important than the sustainability aspect. The aspect of sustainability had an influence on the choice of the transport route for only $15 \%$ of the respondents.

When comparing these results with those of the first question (See Figure 2), an in-consistency was found in the answers. Although most of the respondents are employed in companies where sustainability is a high priority, the sustainability aspect only played a role in the decision-making process of transport selection for three participants. This finding could be an indication that sustainable business trips are currently not yet the top priority in companies.

\section{FIGURE 4 \\ $\mathrm{CO}_{2}$ COMPENSATION OF AIR TRAVEL IN COMPANIES}

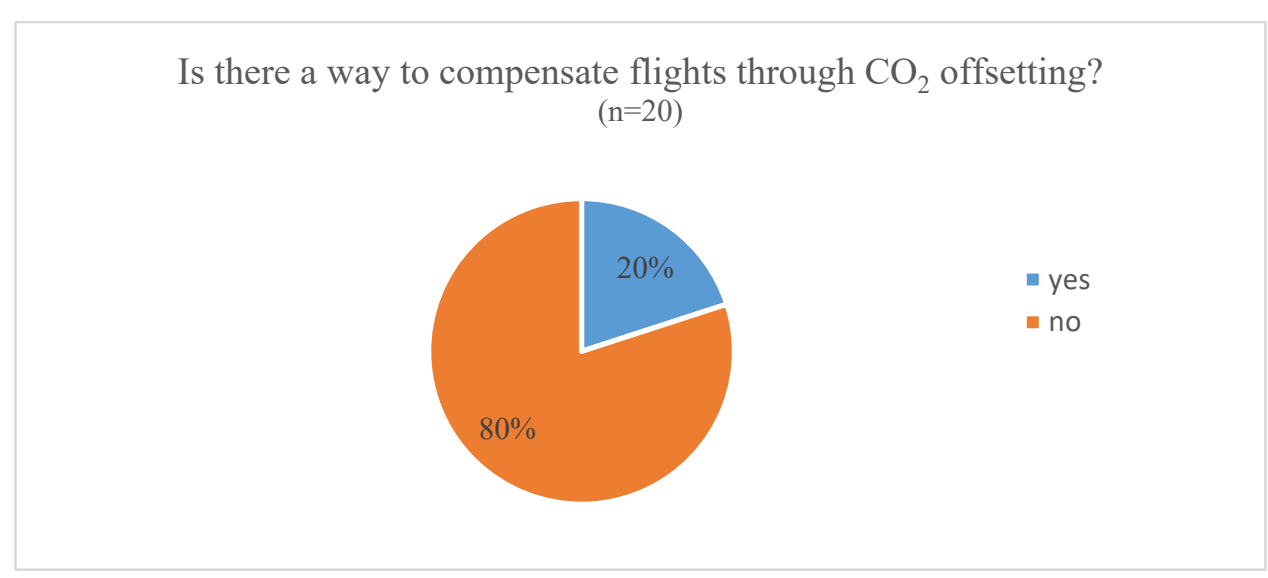

Source: Own Research

In the context of sustainability, the business travelers were also asked whether their company offers the possibility of carbon offsetting (Figure 4). Only $20 \%$ of the respondents mentioned that their companies offer the possibility of $\mathrm{CO}_{2}$ offsetting of business flights. This indicates that the possibility of $\mathrm{CO}_{2}$ offsetting 
in companies does not play a major role yet. Although sustainability plays an important role for most companies, they do not compensate for environmentally harmful domestic business flights.

\section{Results From Sustainable Mobility}

The question regarding the destination airport was the initial question of the questionnaire (Figure 5). It turned out that about two-thirds of the destination airports were more than $500 \mathrm{~km}$ away from the survey location Stuttgart. This includes the German cities of Berlin and Hamburg. One participant each flew to Düsseldorf ( $>400 \mathrm{~km})$ and Bremen $(>600 \mathrm{~km})$ ("Google Maps", n.d.). This might indicate that air travel is the favored means of transport, especially for destinations situated geographically far away from Stuttgart. This would also confirm the respondent's statement that the time factor is more important than sustainability aspects.

\section{FIGURE 5 \\ DESTINATION AIRPORTS FOR DOMESTIC BUSINESS TRIPS DEPARTING FROM STUTTGART}

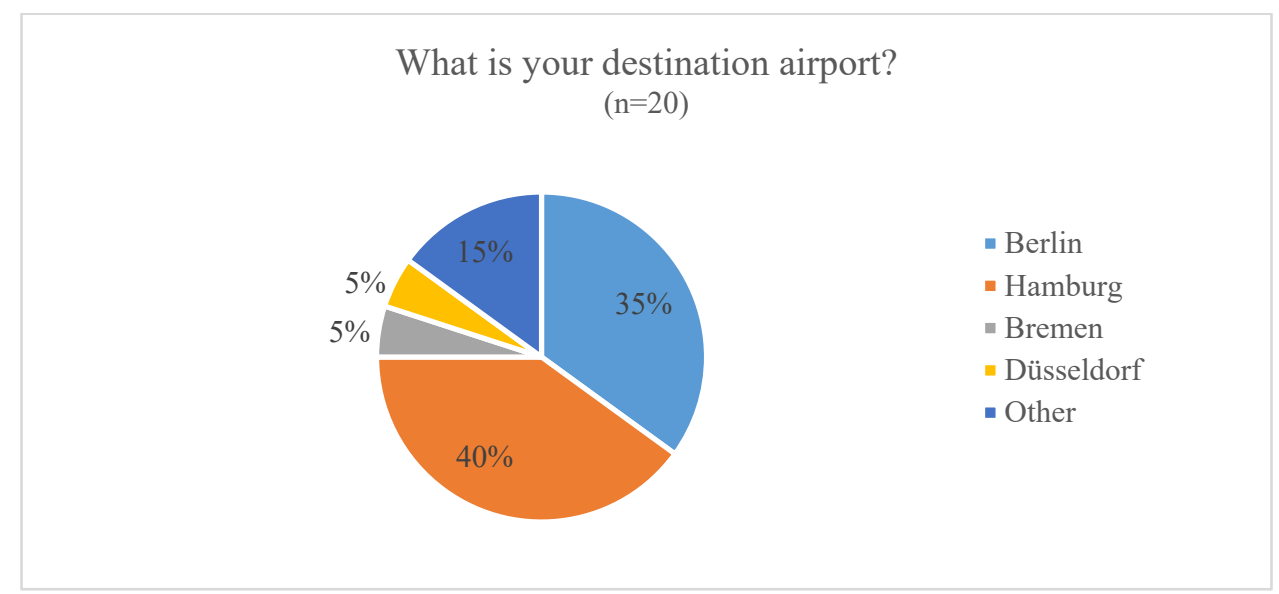

Source: Own Research

Further destination airports mentioned were Dubai, Bucharest and Zagreb. Since the respondents were prefiltered, the respondents should be business travelers on a domestic business trip. It is assumed that these business travelers make a stopover in the domestic country in order to take a subsequent connecting flight to Dubai, Bucharest or Zagreb.

Business travelers were also asked about their main reasons for choosing air travel (Figure 6). Choice was possible between the options "cost", "travel time", "comfort" and "reliability of the means of transport". All selectable factors were mentioned as a reason for the choice of air transport. It became apparent, however, that the time factor was the main decisive factor for choosing the plane, as $95 \%$ of the respondents have mentioned it. Therefore, business travelers were opting for the airplane as a means of transport because of the shorter travel time. This result is in line with the respondent's reasoning for Figure 3, which states that travel time is significantly more important than sustainability aspects. Surprisingly, costs played almost no role in the selection of the means of transport. This result contrasts with the decision-making behavior of private consumers. A study by British Airways has shown that the price is the most important factor for global consumers when choosing a short-haul flight (Mc Bain, 2019). Comfort of the means of transport is even more important for business travelers than the cost.

Additionally, the reliability of the means of transport was important to business travelers. Only less than $50 \%$ of those surveyed cited this as the reason for choosing air travel. According to the results, alternative transport options like the train could not provide the level of reliability as offered by air travel. Assumingly, reliability includes punctuality of departure and arrival or the cancellation rate of the means of transport. 


\section{FIGURE 6 \\ REASONS FOR CHOOSING AIR TRANSPORT}

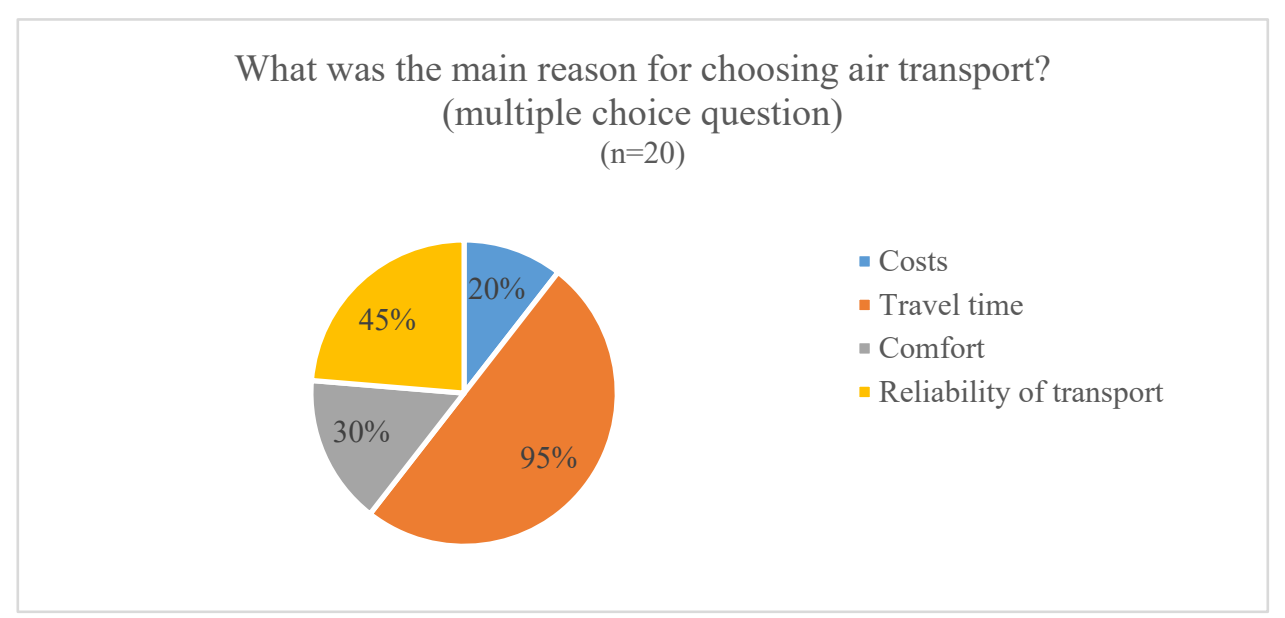

Source: Own Research

Whether the railway was a possible alternative in the selection of the means of transport was questioned afterwards (Figure 7). $75 \%$ of the respondents stated that the railway was not an alternative. As a reason, $55 \%$ of the respondents said that the travel time was too long. Other reasons given were unreliability, unfavorable departure times and establishment of the airplane. If one compares the result with the reasons for choosing air travel as a means of transport, it can be assumed that rail is not an alternative to air travel due to the longer travel time and greater unreliability.

FIGURE 7

\section{THE RAILWAY AS AN ALTERNATIVE TO THE AIRPLANE}

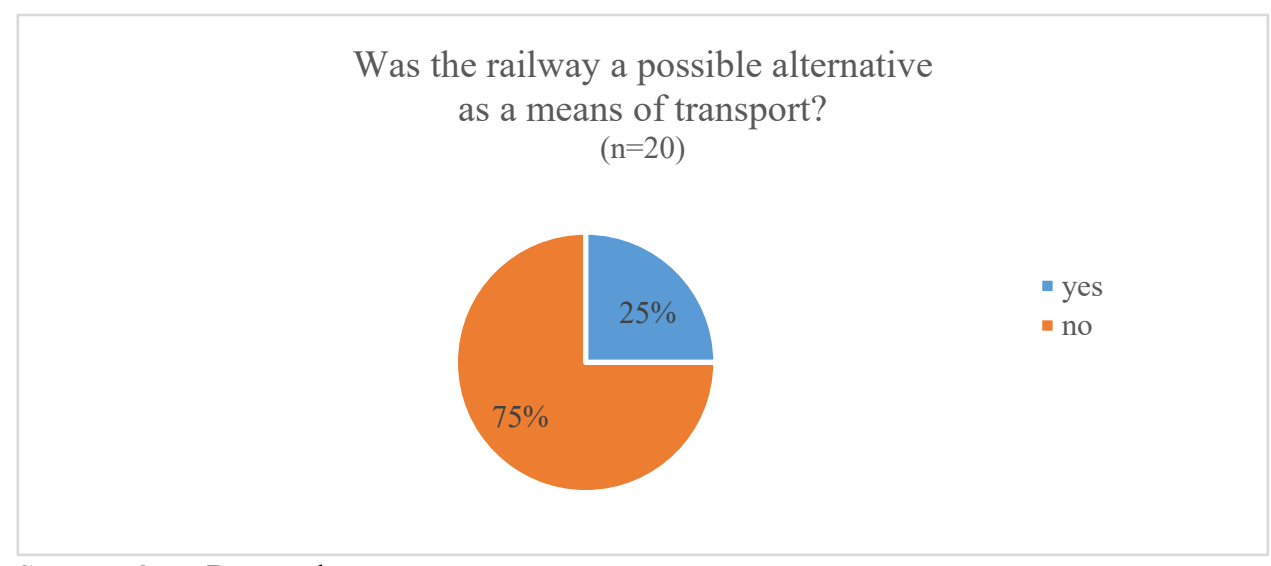

Source: Own Research

\section{Results From Organizational Communication}

Asking for the reason for the business trip served to find out what are possible reasons for business travel in Germany (Figure 8). Respondents had the choice between "customer visit", "trade fair or conference" and "internal company meeting or visit to a company location of their own company". Additionally, respondents had the opportunity to state another reason for travel. $40 \%$ of the respondents and thus the majority stated the reason "customer visit". $35 \%$ of the respondents justified the business trip by physically attending an internal company meeting or visiting a company location. Visits to trade fairs or 
conferences did not play a role for participants in this survey. Other responses included visits to suppliers, workshop participation and cooperation in an international development team as well as networking.

\section{FIGURE 8 \\ REASONS FOR BUSINESS TRIPS}

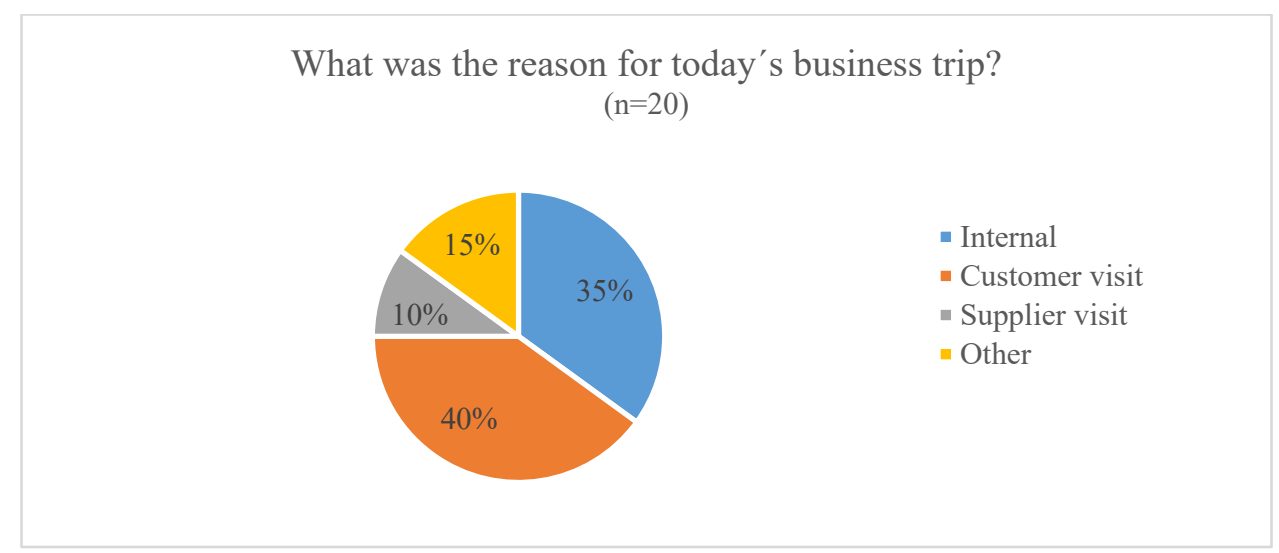

Source: Own Research

During a customer or supplier visit, external stakeholders are met, which is why personal contact is important and therefore a business trip seems necessary. However, the necessity of a business trip could be debated for the $35 \%$ of business travelers who were on their way due to an internal company meeting.

Whether domestic business travel could have been replaced by ICT was examined with the question shown in Figure $9.95 \%$ of the respondents stated that information and communication technologies could not have replaced business travel. Again, the respondents had the opportunity to justify their answers. Two categories were identified in the evaluation of the answers: The complexity of the topic and the personal aspect.

In the first step, the complexity of the topic is addressed. It turned out that ICT, like video conferencing, are generally only suitable for routine appointments, i.e. for recurring issues. The statement of a second participant, who cited the planning of customer-specific events and networking events as reason for his domestic flight, was also subject to this argumentation. In the course of this survey, it was also stated that virtual meetings were less appropriate for reasons of complexity.

If one illuminates the second category, the personality aspect, the results show that face-to-face communication was of great importance for the respondents. Especially for team development measures, critical internal meetings, presentations to the management as well as customer visits or workshops, the human component, according to the respondents, is essential and cannot be replaced by information and communication technologies. 


\section{FIGURE 9 \\ COMMUNICATION TECHNOLOGIES AS SUBSTITUTE FOR BUSINESS TRIPS}

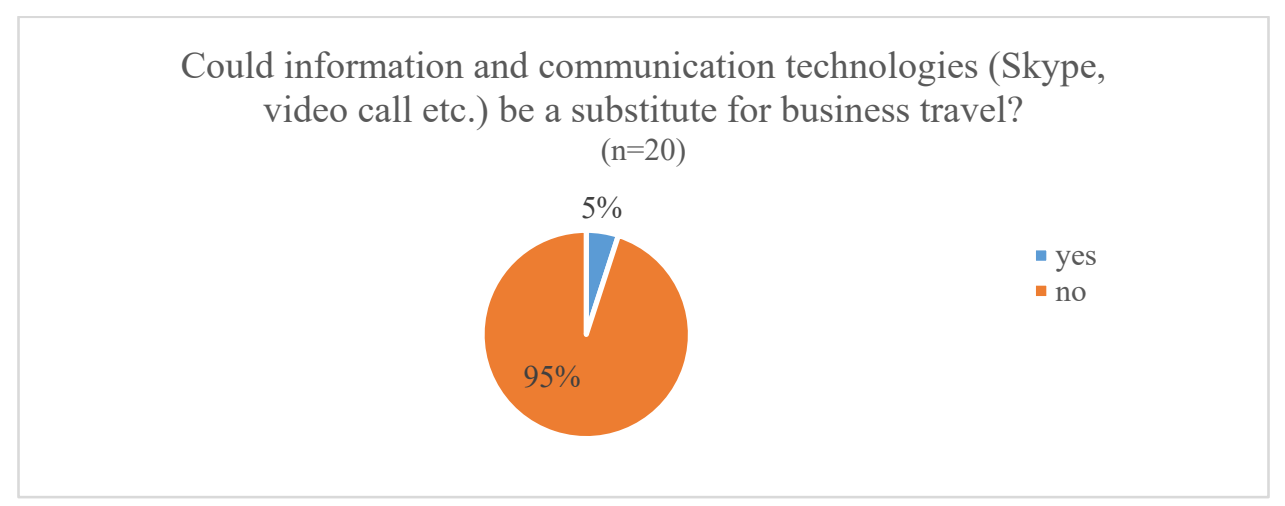

Source: Own Research

\section{SUMMARY AND OUTLOOK}

\section{Summary}

Within the framework of the empirical study, the results of the survey at Manfred Rommel Airport in Stuttgart were processed, analyzed and interpreted. It was determined that the sustainability aspects have a high priority in companies but seem to be not sufficiently anchored in corporate decision-making processes concerning business trips. It was also found that business travelers choose to travel by air mainly because of the shorter travel time and therefore rail is not an alternative at present. Furthermore, it was found that the reasons for business travel were mainly customer visits, internal company meetings and visits to suppliers. Due to the complexity of the topics and personal aspects, information and communication technologies are no alternative to business trips.

\section{Discussion and Conclusion}

Society is in a state of change and awareness of sustainable action is increasing. Organizations play a special role in this debate, as they have a corporate responsibility towards environment and society. However, business trip decisions are often made for reasons of efficiency and comfort at the expense of the environment. After all, $20 \%$ of those surveyed stated that they are employed in companies in which the possibility of offsetting air travel through $\mathrm{CO}_{2}$ offsetting exists. However, it would have been necessary to find out which measures are used to offset $\mathrm{CO}_{2}$ emissions in the respective companies.

In addition, the question in Figure 8 whether the railway would have been a possible alternative means of transport was formulated too imprecisely in the survey. It was not considered in the preparation of the questionnaire that business travelers will continue to fly to a foreign destination airport via a stopover in the domestic country. In order to obtain the desired results, it would have been useful to include the additional remark "Please indicate the domestic intermediate airport" in this question.

\section{Outlook and Suggestions for Further Research}

Shorter travel times and the reliability of the means of transport are the main reasons for choosing air travel for business trips within Germany. As the more environmentally friendly transport option rail in its current form is not a real alternative to air transport in the opinion of respondents, it should be made faster and more reliable in order to make it an attractive solution from a business perspective. In addition, business travel by intercity bus could be tested as a viable alternative to domestic flights. It would also be interesting to do research on how the corona pandemic has altered business trip policies in companies, if ICT measures are going to replace business trips in the long-term and what kind of innovative methods or technologies could be used for both internal and external communication. 
Due to the limited number of participants in this study, the findings only give a qualitative insight into the topic. It would be interesting to see, whether the findings would be reflected in large-scale and thus more representative surveys among business travelers.

\section{REFERENCES}

Aguilera, A. (2008). Business travel and mobile workers. Transportation Research Part A: Policy and Practice, 42(8), 1109-1116. DOI: 10.1016/j.tra.2008.03.005

Atteslander, P. (2010). Methoden der empirischen Sozialforschung (13th Edition). Berlin: Erich Schmidt.

Balderjahn, I. (2013). Nachhaltiges Management und Konsumverhalten. Konstanz/München: UVK Verlagsgesellschaft.

Balzert, H., Schröder, M., \& Schäfer, C. (2010). Wissenschaftliches Arbeiten. Wissenschaft, Quellen, Artefakte, Organisation, Präsentation. Herdecke/Witten: W3L Verlag.

Binder, U. (2013). Nachhaltige Unternehmensführung: Bedeutung, praktische Umsetzung, Erfolgskontrolle. Freiburg/München: Haufe.

Blum, J., de Britto Schiller, R., Löschel, A., Pfeiffer, J., Pittel, K., Potrafke, N., \& Schmitt, A. (2019). Zur Bepreisung von $\mathrm{CO}_{2}$-Emissionen: Ergebnisse aus dem Ökonomenpanel. ifo-Schnelldienst, 72 , 60-65. Retrieved from http://hdl.handle.net/10419/206909

Bode, S., \& Lüdeke, F. (2007). $\mathrm{CO}_{2}$-neutrales Unternehmen - was ist das? uwf UmweltWirtschaftsForum, 15, 265-273. Retrieved from http://www.arrhenius.de/uploads/media/arrhenius_THGBilanzierung_072011.pdf

Deutsches Institut für Interne Revision e.V. (2015). Prüfungsleitfaden Travel Management, Revision von Geschäftsreisen (3th Edition, Vol. 10). Berlin: Erich Schmidt Verlag.

Döring, N., \& Bort, J. (2016). Forschungsmethoden und Evaluation in den Sozial- und Humanwissenschaften (5th Edition). Berlin/Heidelberg: Springer.

European Council. (2019, December 12). European Council conclusions. Retrieved from https://www.consilium.europa.eu/en/meetings/european-council/2019/12/12-13/

Eurostat. (2017, December 20). Glossary: Carbon dioxide emissions. Retrieved from https://ec.europa.eu/eurostat/statistics-explained/index.php/Glossary:Carbon_dioxide_emissions

Flughafen Stuttgart GmbH. (n.d.). Fairport STR. Klimaschutz \& Ressourcen. Stuttgart Airport. Retrieved from https:/www.flughafen-stuttgart.de/fairport-str/klimaschutz-ressourcen/

Flughafen Stuttgart GmbH. (2018). Statistischer Jahresbericht 2018. Retrieved from https:/www.flughafenstuttgart.de/media/306284/statistischer-jahresbericht-2018.pdf

Givoni, M., \& Banister, D. (2006). Airline and railway integration. Transport Policy, 13, 386-397. https://doi.org/10.1016/j.tranpol.2006.02.001

Goede, A.P.H. (2018). $\mathrm{CO}_{2}$ neutral fuels. EPJ Web of Conferences, 189, 1-31. https://doi.org/10.1051/epjconf/20137901005

Google Maps. (n.d.). Retrieved from https://www.google.com/maps

Guerin, T.F. (2017). A demonstration of how virtual meetings can enhance sustainability in a corporate context. Quantified benefits of virtual meetings through video conferencing. Environmental Quality Management, 27, 75-81. DOI: 10.1002/tqem.21515

Heinrichs, H., \& Michelsen, G. (Eds.). (2014). Nachhaltigkeitswissenschaften. Berlin/Heidelberg: Springer.

Janić, M. (2003). High-speed rail and air passenger transport: A comparison of the operational environmental Performance. Proceedings of the Institution of Mechanical Engineers, Part F: Journal of Rail and Rapid Transit, 217, 259-269. DOI: 10.1243/095440903322712865

Kreutzer, R. (2014). Praxisorientiertes Online-Marketing. Konzepte - Instrumente - Checklisten (2th Edition). Wiesbaden: Springer Gabler.

Ludin, D. (2011). Globalisierung als regionale Chance, Erfolgreiche und nachhaltige Strategieentwicklung für mittelständische Brauereien. In Wirtschaftsgeographie und Wirtschaftsgeschichte, edited by Ewald Gläßer et al., Band 8. Lohmar/Köln: EUL Verlag. 
McBain, J. (2019). The Flight of the Future. A ground-breaking study by British Airways. British Airways, Foresight Factory. Retrieved from https://www.foresightfactory.co/2019/07/31/theflight-of-the-future/

Meffert, H., Burmann, C., Kirchgeorg, M., \& Eisenbeiß, M. (2019). Marketing. Grundlagen marktorientierter Unternehmensführung. Konzepte - Instrumente - Praxisbeispiele (13 Edition). Wiesbaden: Springer.

Ministerium für Verkehr Baden-Württemberg (VM). (n.d.). Nachhaltige Mobilität in der Praxis. Definition und Strategie. Retrieved from https://vm.baden-wuerttemberg.de/de/politikzukunft/nachhaltige-mobilitaet/definition-strategie-projekte/grundsaetze/

Poom, A., Orru, K., \& Ahas, R. (2017). The carbon footprint of business travel in the knowledgeintensive service sector. Transportation Research Part D: Transport and Environment, 50, 292304. DOI: $10.1016 /$ j.trd.2016.11.014

Scharschmidt, A., \& Lippelt, J. (2012). Kurz zum Klima: Transport und Emissionshandel in Europa. Ifo Schnelldienst, 65, 26-29. Retrieved from http://hdl.handle.net/10419/165111

Sczcutkowski, A. (2018, February 19). Informations- und Kommunikationssysteme (I.u.K.). Gabler Wirtschaftslexikon. Retrieved from https://wirtschaftslexikon.gabler.de/definition/informationsund-kommunikationssysteme-iuk-39253/version-262666

Statista Research Department. (2018). Verteilung der energiebedingten $\mathrm{CO}_{2}$-Emissionen weltweit nach Sektor im Jahr 2017. Retrieved from https://de.statista.com/statistik/daten/studie/167957/umfrage/verteilung-derco-emissionenweltweit-nach-bereich/

Steinemer, R., Armborst, K., \& Werners, B. (2015). Optimierung der Dienstreisebeschaffung unter Umweltaspekten: Mathematische Modellierung zur Entscheidungsunterstützung. Wirtschaftswissenschaftliches Studium, 44, 495-502. https://doi.org/10.15358/0340-1650-2015-9495

Stock, W., \& Bernecker, T. (2014). Verkehrsökonomie. Eine volkswirtschaftlich-empirische Einführung in die Verkehrswissenschaft (2nd Edition). Wiesbaden: Springer.

Theis-Berglmair, A.M. (2003). Öffentliche Kommunikation. Wiesbaden: Westdeutscher Verlag. Weltgesundheitsorganisation (WHO) - Regionalbüro für Europa. (n.d.). Überwindung der Luftverschmutzung zum Schutz der Gesundheit: Weltumwelttag. Retrieved from https://www.euro.who.int/de/healthtopics/environment-and-health/pages/news/news/2019/6/beatair-pollution-to-protect-health-worldenvironment-day-2019 